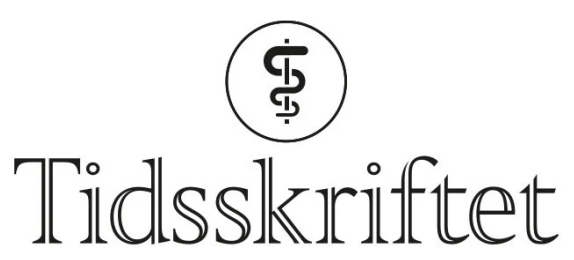

DEN NORSKE LEGEFORENING

\title{
Tidlig aktivitet hos respiratorpasienter - en metaanalyse
}

OVERSIKTSARTIKKEL

\section{HANNA EIKÅS KLEM}

heikas@ous-hf.no

Seksjon for ortopedisk rehabilitering

Ortopedisk avdeling

Oslo universitetssykehus

Hun har bidratt med idé, studiedesign, datainnsamling, analyse og tolkning av data, utarbeiding/revisjon av manus samt godkjenning av innsendte manusversjon. Hun deltok i tillegg med faglige innspill til litteratursøket.

Hanna Eikås Klem er M.Sc. i helsefagvitenskap fra Universitetet i Oslo, spesialfysioterapeut og enhetsleder. Forfatteren har fylt ut ICMJE-skjemaet og oppgir ingen interessekonflikter.

\section{TUVA SOFIE TVEITEN}

Medisinsk fakultet

Universitetet i Oslo

Hun har bidratt med datainnsamling, analyse av data, utarbeiding/revisjon av manus samt godkjenning av innsendte manusversjon.

Tuva Sofie Tveiten er medisinstudent.

Forfatteren har fylt ut ICMJE-skjemaet og oppgir ingen interessekonflikter.

\section{SIGRID BEITLAND}

Institutt for klinisk medisin

Universitetet i Oslo

Hun har bidratt med analyse og tolkning av data, utarbeiding og revisjon av manus samt godkjenning av innsendte manusversjon.

Sigrid Beitland er postdoktor.

Forfatteren har fylt ut ICMJE-skjemaet og oppgir ingen interessekonflikter.

\section{STINE MALERØD}

Seksjon for klinisk service

Nevrologisk avdeling

Oslo universitetssykehus

Hun har bidratt med datainnsamling, analyse av data, utarbeiding/revisjon av manus samt godkjenning av innsendte manusversjon.

Stine Malerød er spesialfysioterapeut og fagutviklingsfysioterapeut innen somatikk.

Forfatteren har fylt ut ICMJE-skjemaet og oppgir ingen interessekonflikter.

\section{DORIS TOVE KRISTOFFERSEN}

Område for helsetjenester

Folkehelseinstituttet

Hun har bidratt med analyse og tolkning av data, utarbeiding/revisjon av manus samt godkjenning av innsendte manusversjon.

Doris Tove Kristoffersen er forsker og statistiker.

Forfatteren har fylt ut ICMJE-skjemaet og oppgir ingen interessekonflikter. 
Biblioteket

Luftkrigsskolen

Forsvarets Høgskole

Trondheim

Hun har bidratt i litteratursøk, revisjon av manus samt godkjenning av innsendte manusversjon.

Terese Dalsnes er spesialbibliotekar. Hun var spesialbibliotekar ved Medisinsk bibliotek, Ullevål sykehus under arbeidet med søk til denne metaanalysen.

Forfatteren har fylt ut ICMJE-skjemaet og oppgir ingen interessekonflikter.

\section{MARIA BEATE NUPEN-STIENG}

Seksjon for fysioterapi og sosialmedisin

Avdeling for klinisk service

Oslo universitetssykehus

Hun har bidratt med vurdering og sammenstilling av data, revisjon av manus samt godkjenning av innsendte manusversjon.

Maria Beate Nupen-Stieng er spesialfysioterapeut.

Forfatteren har fylt ut ICMJE-skjemaet og oppgir ingen interessekonflikter.

\section{LILLEBETH LARUN}

Område for helsetjenester

Folkehelseinstituttet

Hun har bidratt med studiedesign, analyse og tolkning av data, utarbeiding/revisjon av manus samt

godkjenning av innsendte manusversjon.

Lillebeth Larun er seniorforsker og førsteamanuensis.

Forfatteren har fylt ut ICMJE-skjemaet og oppgir følgende interessekonflikter: Hun var veileder for Hanna Klem da hun skrev masteroppgave ved Universitetet i Oslo.

\section{BAKGRUNN}

I Norge ble nesten 8500 pasienter behandlet med respirator i 2019. Vi har undersøkt hvilken effekt tidlig aktivitet hos voksne respiratorbehandlede intensivpasienter har på varighet av respiratorbehandling, avvenningstid fra respirator, dødelighet, liggetid og uheldige hendelser.

KUNNSKAPSGRUNNLAG

Vi gjennomførte et systematisk litteratursøk etter randomiserte, kontrollerte studier i ni databaser. To forfattere selekterte studier, ekstraherte data og vurderte tilliten til dokumentasjonen med GRADE-metoden.

\section{RESULTATER}

3270 sammendrag og titler ble lest. Vi inkluderte 17 studier med 1805 pasienter og middels til lav risiko for systematisk skjevhet. Analysene viste effekt av tidlig mobilisering med gjennomsnittlig kortere respiratorbehandling (-1,43 døgn; $95 \% \mathrm{KI}-2,68$ til-0,18, p = o,02) og kortere liggetid i intensivavdeling (-1,08 døgn; $95 \% \mathrm{KI}-1,95$ til-0,21, p = o,02), med middels tillit til dokumentasjonen. Inspirasjonsmuskeltrening viste ingen effekt på varighet av respiratorbehandling $(-0,11 ; 95 \% \mathrm{KI}-1,76$ til 1,53, $\mathrm{p}=0,89)$ eller avvenningstid fra respirator $(-0,33$; $95 \% \mathrm{KI}-1,31$ til o,65, $\mathrm{p}=0,51)$, med liten tillit til dokumentasjonen. Verken tidlig mobilisering eller inspirasjonsmuskeltrening påvirket dødelighet. Det ble rapportert få uheldige hendelser.

\section{FORTOLKNING}

Analysene viser at tidlig mobilisering er trygt og kan gi kortere respiratorbehandlingstid og kortere liggetid i intensivavdeling, men tiltakene har ikke effekt på dødelighet. Inspirasjonsmuskeltrening viste ingen effekt på utfallsmålene.

I Norge ble det i 2019 registrert 14354 behandlede pasienter ved intensivavdelinger, hvorav 59,2 \% fikk respiratorbehandling (1). Pasienter som behandles med respirator på intensivavdeling, er utsatt for svekkelse av bevegelses- og respirasjonsmuskler som følge av intensiververvet muskelsvakhet (ㅁ, 3). Muskelsvakheten kan inntreffe få timer etter oppstart av intensivbehandlingen, og graden av svekkelse kan påvirke liggetid på sykehus, overlevelse samt varighet og resultat av rehabilitering (르). 
Intensivmedisinen har den siste tiden dreid mot at pasienter som tolererer det, skal vekkes tidlig fra sedasjon, bevege seg og puste så aktivt som tilrådelig (4). Samtidig opplever personale på intensivavdelinger at det eksisterer barrierer som vanskeliggjør intervensjonene (5).

Tiltakene innenfor tidlig mobilisering spenner fra passive øvelser og posisjonering til aktive øvelser og forflytning. Inspirasjonsmuskeltrening er spesifikk trening av inspirasjonsmuskulatur som kan gjøres mens pasienten får respiratorbehandling.

I tidligere oversiktsartikler er det vist at tidlig mobilisering og inspirasjonsmuskeltrening hos intensivpasienter kan understøtte avvenningsprosessen fra respirator og ha gunstig effekt på behandlingsresultatet (5-7.). Disse har inkludert studier av ulik metodisk kvalitet, også lav. Bare i et fåtall av disse oversiktsartiklene er det vurdert tillit til dokumentasjonen ved GRADE-metoden (Grading of Recommendations Assessment, Development and Evaluation) (ㅁ). Det er publisert flere relevante studier siden forrige kunnskapsoppsummering. Vi inkluderte kun randomiserte, kontrollerte studier med aktive tiltak hos intuberte eller trakeotomerte pasienter og ekskluderte studier med lav metodisk kvalitet, i tillegg til at vi benyttet GRADE-metoden.

Formålet med oversikten var å sammenligne tidlig, aktiv mobilisering (heretter kalt tidlig mobilisering) og inspirasjonsmuskeltrening med standard behandling hos voksne intensivpasienter som fikk respiratorbehandling.

\section{Metode}

Vi har rapportert oversikten i henhold til PRISMAs sjekkliste for systematiske oversikter (9.). Protokollen er publisert i PROSPERO (International Prospective Register of Systematic Reviews) med registreringsnummer CRD42017058780 (10). Det ble, før oppstart av arbeidet, gjort en protokollendring der avvenningstid ble føyd til primærutfallsmålene.

Seleksjonskriteriene inkluderte pasienter over 18 år behandlet med respirator i intensivavdeling, nærmere bestemt oralintuberte eller trakeotomerte pasienter. Intervensjonene var respirasjonsmuskeltrening, ledet aktive og aktive øvelser for ekstremitetene, mobilisering til sengekant, til sittende (stol), stående eller gående stilling samt bruk av sengesykkel. Kontrollgruppene fikk ingen behandling, annen behandling eller narrebehandling. Primære utfallsmål var varighet av respiratorbehandling, avvenningstid fra respirator og dødelighet på sykehus, ved 1-3 måneder, 1-6 måneder og etter ett år. Sekundære utfallsmål var liggetid i intensivavdeling og på sykehus samt uheldige hendelser. Cochrane definerer uheldige hendelser (adverse events) som et ugunstig eller skadelig utfall som forekommer under eller etter en intervensjon, men som ikke nødvendigvis er forårsaket av denne. Det skilles på alvorlige og mindre alvorlige uheldige hendelser (1ㅡ). Vi inkluderte kun publiserte randomiserte, kontrollerte studier (RCT).

Vi gjennomførte, med hjelp fra spesialbibliotekar, et systematisk søk etter litteratur publisert i perioden 1.1.20o6-27.4.2020 i databasene Ovid MEDLINE, Ovid EMBASE, Cinahl, PubMed, PEDro, SweMed+, Allied and Complementary Medicine Database (AMED), The Cochrane Library og OTseeker. Vi kombinerte tekst- og emneord som beskrev populasjon og intervensjon. Søket ble begrenset til engelsk og skandinavisk språk og randomiserte, kontrollerte studier og systematiske oversikter (se appendiks 1 for detaljert søkestrategi). I tillegg ble UpToDate, Mobilization Network og Intensive Care Medicine, tidsskriftet til The European Society of Intensive Care Medicine, håndsøkt. Seleksjon av studier ble gjort ved at titler og sammendrag, og deretter fulltekstartikler, ble gjennomgått av to forfattere uavhengig av hverandre. Seleksjonen ble gjort i henhold til forhåndsdefinerte og piloterte seleksjonskriterier (ramme 1).

\section{Ramme 1 Kriterier for utvelgelse av studier.}

\section{Design}

Randomiserte, kontrollerte studier

\section{Deltakere}

Pasienter over 18 år

Pasienter som ble behandlet med respirator på intensivavdeling, oralintubert eller trakeotomert

\section{Intervensjon}


Respirasjonsmuskeltrening

Aktive og ledet aktive øvelser for ekstremitetene

Mobilisering til sengekant, til stol, stående eller gående stilling

Sengesykkel

\section{Sammenligning}

Kontrollgruppe som får annen eller ingen behandling

\section{Primcere utfallsmål}

Varighet av respiratorbehandling

Avvenningstid fra respirator

Dødelighet på sykehus, etter 1-3 måneder, 1-6 måneder og etter ett år

\section{Sekundcere utfallsmål}

Liggetid i intensivavdeling

Liggetid på sykehus

Pasientsikkerhet, uheldige hendelser

\section{Publiseringsdato og språk}

Publiseringsdato 1.1.2006-27.4.2020

Engelsk eller skandinavisk språk

Kun publiserte studier ble inkludert

\section{Eksklusjonskriterier}

Pasientene hadde skade eller sykdomsspesifikk svekkelse i muskulaturen

Intervensjonen var passiv eller overveiende passiv

Studier med andre utfallsmål, publiseringsår og språk

Studier med høy risiko for systematisk skjevhet

Dataekstraksjon til studiekarakteristikker (tabell 1) ble foretatt av én forfatter og sjekket av en annen. Data til metaanalysene ble ekstrahert av to forfattere uavhengig av hverandre. Dataene ble analysert i Review Manager 5 (RevMan 5) i en tilfeldig effektmodell, ettersom det eksisterte

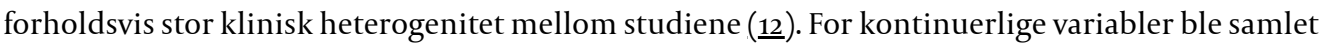
effekt presentert som gjennomsnittsforskjell mellom gruppene (MD) og 95\% konfidensintervall (KI). For dikotome variabler ble samlet effekt presentert som oddsratio (OR), et effektmål for odds for en hendelse på angitt tidspunkt, og 95 KI. Statistisk heterogenitet mellom studiene er oppgitt i prosent som $I^{2}$.

\section{Tabell 1}

Beskrivelse av de inkluderte randomiserte kontrollerte studiene $(\mathrm{n}=17)$.

\begin{tabular}{|c|c|c|c|c|}
\hline $\begin{array}{l}\text { Førsteforfatter, } \\
\text { årstall }\end{array}$ & Land & Deltakere & Intervensjon & Kontroll \\
\hline $\begin{array}{l}\text { Amundadottir, } \\
2019 \text { (31) }\end{array}$ & Island & $\begin{array}{l}\mathrm{n}=50 \\
\text { Blandet }\end{array}$ & $\begin{array}{l}\text { Tidlig mobilisering } 48 \mathrm{t} \\
\text { etter inklusjon, } \\
20 \text { minutter eller mer to } \\
\text { ganger daglig + standard } \\
\text { behandling }\end{array}$ & $\begin{array}{l}\text { Tidlig mobilisering } 96 \mathrm{t} \\
\text { etter inklusjon, én gang } \\
\text { daglig + standard } \\
\text { behandling }\end{array}$ \\
\hline $\begin{array}{l}\text { Burtin, } 2009 \\
\text { (15) }\end{array}$ & Belgia & $\begin{array}{l}\mathrm{n}=90 \\
\text { Kirurgisk } \\
\text { og } \\
\text { medisinsk }\end{array}$ & $\begin{array}{l}\text { Sengesykling i } \\
20 \text { minutter, fem dager i } \\
\text { uka + standard } \\
\text { behandling }\end{array}$ & $\begin{array}{l}\text { Standard behandling } \\
\text { (lungefysioterapi og } \\
\text { passiv/aktiv mobilisering av } \\
\text { ekstremiteter + ev. } \\
\text { mobilisering opp av seng) }\end{array}$ \\
\hline
\end{tabular}




\begin{tabular}{|c|c|c|c|c|}
\hline $\begin{array}{l}\text { Førsteforfatter, } \\
\text { årstall }\end{array}$ & Land & Deltakere & Intervensjon & Kontroll \\
\hline $\begin{array}{l}\text { Condessa, } \\
2013(22)\end{array}$ & Brasil & $\begin{array}{l}\mathrm{n}=92 \\
\text { lkke } \\
\text { beskrevet }\end{array}$ & $\begin{array}{l}\text { Inspirasjonsmuskeltrening } \\
\text { to ganger daglig sju } \\
\text { dager i uka + standard } \\
\text { behandling }\end{array}$ & $\begin{array}{l}\text { Standard behandling } \\
\text { (lungefysioterapi og } \\
\text { passiv/aktiv mobilisering av } \\
\text { ekstremiteter + } \\
\text { posisjonering) }\end{array}$ \\
\hline $\begin{array}{l}\text { Dantas, } 2012 \\
(17)\end{array}$ & Brasil & $\begin{array}{l}\mathrm{n}=28 \\
\text { Generell }\end{array}$ & $\begin{array}{l}\text { Tidlig mobilisering etter } \\
\text { protokoll to ganger daglig } \\
\text { sju dager i uka, blant } \\
\text { annet øvelser for } \\
\text { ekstremitetene og } \\
\text { sengesykling }\end{array}$ & $\begin{array}{l}\text { Standard behandling } \\
\text { (passive øvelser for } \\
\text { ekstremitetene) }\end{array}$ \\
\hline $\begin{array}{l}\text { Dong, } 2014 \\
\text { (27) }\end{array}$ & Kina & $\begin{array}{l}\mathrm{n}=60 \\
\text { Generell }\end{array}$ & $\begin{array}{l}\text { Tidlig mobilisering to } \\
\text { ganger daglig }\end{array}$ & Ikke beskrevet \\
\hline $\begin{array}{l}\text { Dong, } 2016 \\
\text { (16) }\end{array}$ & Kina & $\begin{array}{l}\mathrm{n}=106 \\
\text { Koronar } \\
\text { bypass- } \\
\text { operasjon }\end{array}$ & $\begin{array}{l}\text { Preoperativ informasjon } \\
\text { og tidlig mobilisering to } \\
\text { ganger daglig }\end{array}$ & $\begin{array}{l}\text { Rehabilitering med hjelp fra } \\
\text { familien etter utskrivning } \\
\text { fra intensivavdeling }\end{array}$ \\
\hline $\begin{array}{l}\text { Dos Santos } \\
2018(23)\end{array}$ & Brasil & $\begin{array}{l}\mathrm{n}=28 \\
\text { Generell }\end{array}$ & Aktive øvelser med strikk & $\begin{array}{l}\text { Passive øvelser og } \\
\text { posisjonering }\end{array}$ \\
\hline $\begin{array}{l}\text { Eggmann, } \\
2018(29)\end{array}$ & Sveits & $\begin{array}{l}\mathrm{n}=115 \\
\text { Blandet }\end{array}$ & $\begin{array}{l}\text { Tidlig, progressiv } \\
\text { mobilisering med } \\
\text { sengesykkel inntil tre } \\
\text { ganger daglig i } \\
\text { ukedagene + standard } \\
\text { behandling }\end{array}$ & $\begin{array}{l}\text { Standard behandling (tidlig } \\
\text { mobilisering, } \\
\text { lungefysioterapi og } \\
\text { passive/aktive øvelser) }\end{array}$ \\
\hline $\begin{array}{l}\text { Hodgson, } 2016 \\
\text { (18) }\end{array}$ & $\begin{array}{l}\text { Australia/New } \\
\text { Zealand }\end{array}$ & $\begin{array}{l}\mathrm{n}=50 \\
\text { Blandet }\end{array}$ & $\begin{array}{l}\text { Tidlig mobilisering etter } \\
\text { protokoll én time daglig }\end{array}$ & $\begin{array}{l}\text { Enhetens vanlige tiltak: } \\
\text { passiv bevegelse }\end{array}$ \\
\hline Kho, 2019 (30) & Canada & $\begin{array}{l}\mathrm{n}=66 \\
\text { Medisinsk } \\
\text { og } \\
\text { kirurgisk }\end{array}$ & $\begin{array}{l}\text { Sengesykling + standard } \\
\text { behandling }\end{array}$ & $\begin{array}{l}\text { Standard behandling } \\
\text { (passive/aktive øvelser og } \\
\text { tidlig mobilisering) }\end{array}$ \\
\hline $\begin{array}{l}\text { Martin, } 2011 \\
(21)\end{array}$ & USA & $\begin{array}{l}\mathrm{n}=69 \\
\text { Generell } \\
\text { kirurgi- og } \\
\text { brannskade }\end{array}$ & $\begin{array}{l}\text { Inspirasjonsmuskeltrening } \\
\text { fem dager i uka }\end{array}$ & $\begin{array}{l}\text { Pusteøvelser i narre- } \\
\text { inspirasjonsmuskeltrenings- } \\
\text { apparat, fem ganger i uka }\end{array}$ \\
\hline $\begin{array}{l}\text { Morris, } 2016 \\
(20)\end{array}$ & USA & $\begin{array}{l}\mathrm{n}=300 \\
\text { Medisinsk }\end{array}$ & $\begin{array}{l}\text { Tidlig, intensiv } \\
\text { mobilisering etter } \\
\text { protokoll tre ganger } \\
\text { daglig }\end{array}$ & $\begin{array}{l}\text { Standard behandling } \mathrm{i} \\
\text { ukedagene når ordinert }\end{array}$ \\
\hline $\begin{array}{l}\text { Moss, } 2016 \\
(19)\end{array}$ & USA & $\begin{array}{l}\mathrm{n}=120 \\
\text { Blandet }\end{array}$ & $\begin{array}{l}\text { Nivåinndelt tidlig } \\
\text { mobilisering daglig }\end{array}$ & $\begin{array}{l}\text { Standard behandling tre } \\
\text { ganger i uka (passive } \\
\text { øvelser, posisjonering og } \\
\text { funksjonell rehabilitering) }\end{array}$ \\
\hline $\begin{array}{l}\text { Schaller, } 2016 \\
(25)\end{array}$ & Tyskland & $\begin{array}{l}\mathrm{n}=200 \\
\text { Kirurgisk }\end{array}$ & $\begin{array}{l}\text { Tidlig mobilisering i fem } \\
\text { nivåer }\end{array}$ & $\begin{array}{l}\text { Mobilisering etter } \\
\text { retningslinjene til } \\
\text { avdelinger }\end{array}$ \\
\hline $\begin{array}{l}\text { Schweickert, } \\
2009(26)\end{array}$ & USA & $\begin{array}{l}\mathrm{n}=104 \\
\text { Medisinsk }\end{array}$ & Tidlig mobilisering daglig & $\begin{array}{l}\text { Standard behandling når } \\
\text { ordinert }\end{array}$ \\
\hline $\begin{array}{l}\text { Tonella, } 2017 \\
(24)\end{array}$ & Brasil & $\begin{array}{l}\mathrm{n}=19 \\
\text { Blandet }\end{array}$ & $\begin{array}{l}\text { Elektronisk inspirasjons- } \\
\text { muskeltrening to ganger } \\
\text { daglig }\end{array}$ & $\begin{array}{l}\text { Intermitterende } \\
\text { forstøverbehandling }\end{array}$ \\
\hline $\begin{array}{l}\text { Wright, } 2018 \\
(28)\end{array}$ & Storbritannia & $\begin{array}{l}\mathrm{n}=308 \\
\text { Blandet }\end{array}$ & $\begin{array}{l}\text { Intensiv tidlig } \\
\text { mobilisering } 90 \text { minutter i } \\
\text { ukedagene }\end{array}$ & $\begin{array}{l}\text { Standard behandling } \\
30 \text { minutter i ukedagene }\end{array}$ \\
\hline
\end{tabular}


Kontinuerlige variabler oppgitt som median og interkvartilbredde ble regnet om til gjennomsnitt og standardavvik (SD) for å kunne inngå i metaanalysene (13). Vi undersøkte ved sensitivitetsanalyser om resultatene i metaanalysene ble endret ved inklusjon av disse studiene. Metodisk kvalitet ble vurdert av to uavhengige forfattere etter kriteriene angitt i Cochranes verktøy for estimering av risiko for systematisk skjevhet (14).). Ved uenighet ble en tredjeperson konsultert. Sensitivitetsanalyser ble gjort for å undersøke om risiko for systematisk skjevhet påvirket resultatene. Det ble gjort subgruppeanalyser innenfor studiene av tidlig mobilisering, med hensyn til antall behandlinger og aktivitetsgraden i kontrollgruppenes intervensjon. To forfattere undersøkte tilliten til dokumentasjonen i studiene med lav risiko for systematisk skjevhet ved hjelp av GRADE-metoden (ㅁ). Som ledd i denne metoden ble publikasjonsskjevhet vurdert.

\section{Resultater}

3270 unike titler og sammendrag ble identifisert og lest. Av disse ble 90 artikler lest i fulltekst. 17 studier ble inkludert (15-31) og 73 ekskludert (figur 1).

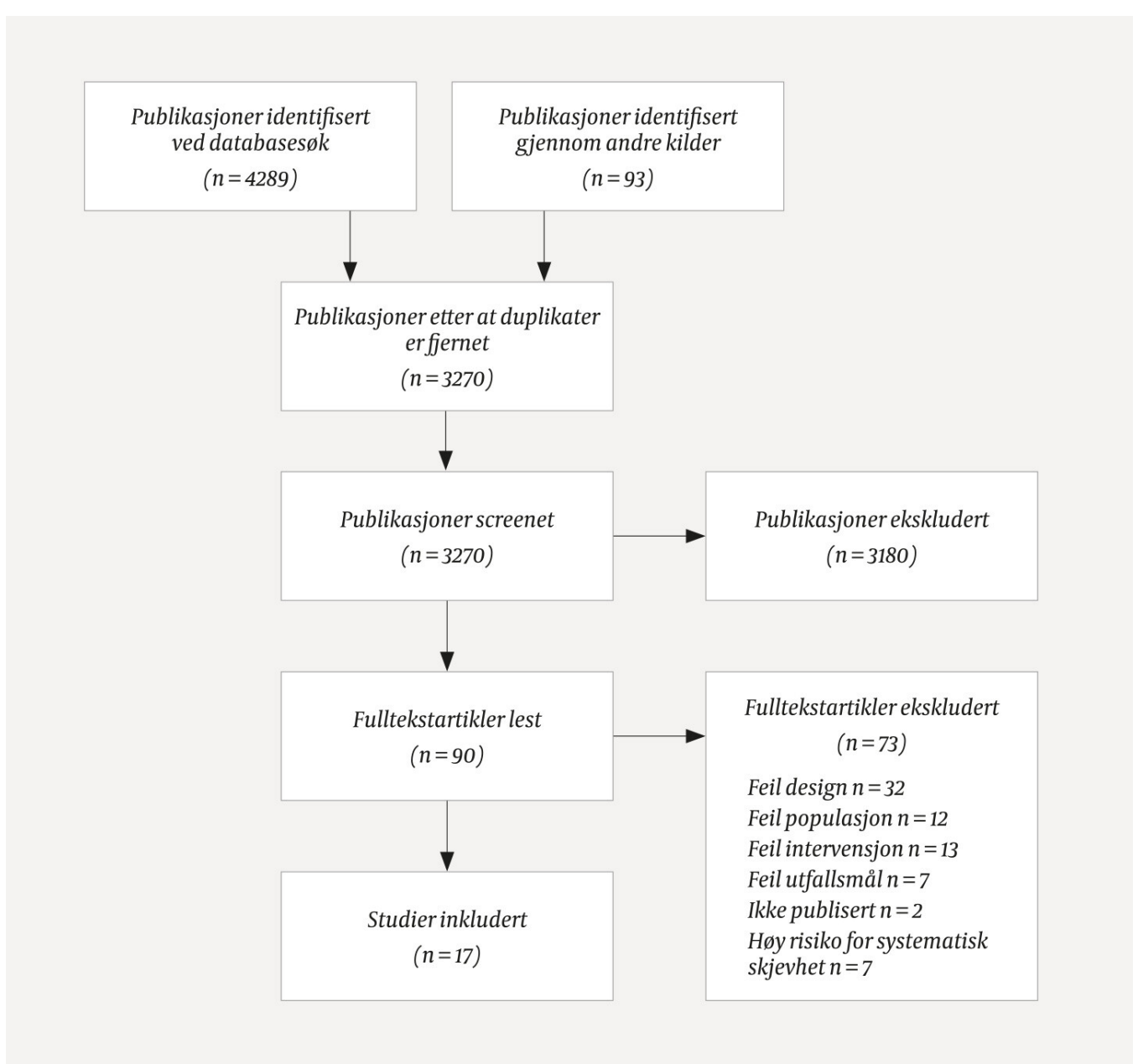

Figur 1 Flytdiagram over utvelgelsesprosessen av studier i kunnskapsgrunnlaget.

Totalt 1805 pasienter ble inkludert og antall deltakere varierte mellom 19 og 308. Det er oppgitt resultater for til sammen 1782 pasienter. Gjennomsnittlig alder var i underkant av 6o år, og det var $56,2 \%$ menn. I 13 av studiene var det pasienter fra blandet eller ikke spesifisert intensivavdeling (15), (17-19).), (21-24), (27-31). To av studiene inkluderte pasienter fra medisinsk intensivavdeling (15,17.) og to fra kirurgisk intensivavdeling $(\mathbf{1 9}, \underline{21})$. Det var noe varierende sykelighet blant deltakerne (appendiks 2). Intervensjonen bestod av inspirasjonsmuskeltrening i tre studier ( $\underline{2} 4$, 27.)sengesykling i fire studier $(\underline{\mathbf{2 0}}, \underline{26})$ og øvrig tidlig mobilisering i ti studier $(\underline{16}),(\underline{18-20}),(\underline{2} 3),(\underline{25}=$ $\underline{28})$, (31). Vi identifiserte ingen studier med ekspirasjonstrening som møtte seleksjonskriteriene våre. Intervensjonene i kontrollgruppene er i analysene kalt standard behandling, og bestod i ingen 
behandling, annen behandling eller narrebehandling. Et fellestrekk for kontrollgruppene var at deltakerne her fikk mer passive, senere eller mindre intensive tiltak enn deltakerne $\mathrm{i}$ intervensjonsgruppene.

Risiko for systematisk skjevhet var lav i ni og middels i åtte av de inkluderte studiene (figur 2). Ingen av traktdiagrammene (funnel plot) indikerte publikasjonsskjevhet i analysene (appendiks 3 ). Resultater fra studiene med lav risiko for systematisk skjevhet presenteres i det følgende.

\begin{tabular}{|c|c|c|c|c|c|c|c|}
\hline Amundadottir(2019) & + & $?$ & $\theta$ & + & + & + & $\theta$ \\
\hline Burtin (2009) & + & + & $\Theta$ & $?$ & $\theta$ & $?$ & $\odot$ \\
\hline Condessa (2013) & $\odot$ & $\odot$ & $\Theta$ & $\odot$ & $\odot$ & $\odot$ & $\odot$ \\
\hline Dantas(2012) & $\odot$ & $\odot$ & $\ominus$ & $?$ & $\ominus$ & $\odot$ & $\odot$ \\
\hline Dong(2014) & + & $?$ & $\theta$ & $?$ & + & $?$ & $\odot$ \\
\hline Dong(2016) & + & $?$ & $\theta$ & 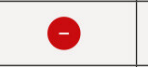 & $\odot$ & $?$ & $\odot$ \\
\hline Dos Santos (2018) & + & $?$ & $\odot$ & $?$ & 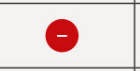 & $\odot$ & $\Theta$ \\
\hline Eggmann (2018) & $\odot$ & + & $\Theta$ & $\odot$ & $?$ & 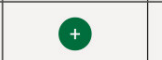 & $\odot$ \\
\hline Hodgson (2016) & + & $\odot$ & $\Theta$ & + & + & + & $\Theta$ \\
\hline Kho(2019) & $\odot$ & + & $\theta$ & + & 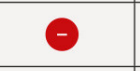 & $\odot$ & $\odot$ \\
\hline Martin (2011) & + & + & + & $?$ & + & + & + \\
\hline Morris (2016) & $\odot$ & $?$ & $\Theta$ & $\odot$ & $\odot$ & $\odot$ & $\odot$ \\
\hline $\operatorname{Moss}(2016)$ & + & $?$ & $\Theta$ & $\odot$ & $\odot$ & $\odot$ & $\Theta$ \\
\hline Schaller(2016) & 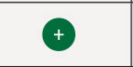 & + & $\theta$ & $\oplus$ & + & + & + \\
\hline Schweickert (2009) & + & + & $\Theta$ & + & + & + & $\odot$ \\
\hline Tonella (2017) & + & + & $\Theta$ & $?$ & $\odot$ & $?$ & 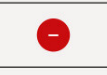 \\
\hline \multirow[t]{2}{*}{ Wright(2017) } & + & + & $\Theta$ & $\Theta$ & + & + & + \\
\hline & $\begin{array}{l}\text { Generering } \\
\text { avrando- } \\
\text { miserings- } \\
\text { sekvens }\end{array}$ & $\begin{array}{l}\text { Skjult } \\
\text { fordeling til } \\
\text { grupper }\end{array}$ & $\begin{array}{l}\text { Blindingav } \\
\text { deltakere } \\
\text { og personell }\end{array}$ & $\begin{array}{l}\text { Blinding av } \\
\text { utfalls- } \\
\text { vurderer }\end{array}$ & $\begin{array}{l}\text { Frafallved } \\
\text { oppfolging }\end{array}$ & $\begin{array}{l}\text { Selektiv rap- } \\
\text { portering }\end{array}$ & $\begin{array}{l}\text { Annen } \\
\text { skjevhet }\end{array}$ \\
\hline
\end{tabular}

Figur 2 Oversikt over risiko for systematisk skjevhet.

PRIMARUTFALL

Tidlig mobilisering versus standard behandling ga kortere respiratorbehandling $(-1,43$ døgn; $95 \%$ $\mathrm{KI}-2,68$ til $-\mathrm{O}, 18, \mathrm{p}=\mathrm{o}, 02$, fire studier, 335 pasienter), med middels tillit til dokumentasjonen (figur 3).

\begin{tabular}{|c|c|c|c|c|c|c|c|c|c|c|}
\hline \multirow{2}{*}{$\begin{array}{l}\text { Forsteforfatter } \\
\text { (årstall) }\end{array}$} & \multicolumn{3}{|c|}{ Tidlig mobilisering } & \multicolumn{3}{|c|}{ Standard behandling } & \multirow{2}{*}{$\begin{array}{l}\text { Gjennomsnittsforskjell, } \\
\text { tilfeldig effekt, } 95 \% \mathrm{KI}\end{array}$} & \multirow{2}{*}{\multicolumn{3}{|c|}{$\begin{array}{l}\text { Gjennomsnittsforskjell } \\
\text { tilfeldig effekt, } 95 \% \mathrm{KI}\end{array}$}} \\
\hline & Gjennomsnitt & $S D$ & Antall & Gjennomsnitt & SD & Antall & & & & \\
\hline Eggmann (2018) & 7,2 & 7,3 & 58 & 6,83 & 6,31 & 57 & $0,37[-2,12 ; 2,86]$ & & $\square-$ & \\
\hline Hodgson (2016) & 6,3 & 5,07 & 29 & 8,0 & 5,57 & 21 & $-1,70[-4,71 ; 1,31]$ & & $\begin{array}{l:l}1 \\
-1\end{array}$ & \\
\hline Kho (2019) & 10,17 & 9,27 & 36 & 10,67 & 10,9 & 30 & $-0,50[-5,44 ; 4,44]$ & & : & \\
\hline Schweickert (2009) & 4,33 & 3,82 & 49 & 6,57 & 4,26 & 55 & $-2,24[-3,79 ;-0,69]$ & & -1 & \\
\hline Totalt $(95 \% \mathrm{KI})$ & & & 172 & & & 163 & $-1,43[-2,68 ;-0,18]$ & & $<$ & \\
\hline \multicolumn{8}{|c|}{ Heterogenitet: Tau $^{2}=0,12 ;$ khikvadrattest $=3,21$, frihetsgrad $(d f)=3(p=0,36) ; I^{2}=6 \%$} & -10 & -5 & 5 \\
\hline \multicolumn{8}{|c|}{ Test for effekt: $Z=2,25(p=0,02)$} & \multicolumn{3}{|c|}{ Tidlig mobilisering Standard behandlin } \\
\hline
\end{tabular}

Figur 3 Balansediagram for utfallsmålet varighet av respiratorbehandling angitt $\mathrm{i}$ antall døgn. Sammenligning mellom tidlig mobilisering og standard behandling. De inkluderte studiene har lav risiko for systematisk skjevhet.

Ved inklusjon av studier med middels risiko for systematisk skjevhet ble det betydelig større statistisk heterogenitet i analysene, $\mathrm{I}^{2}=78 \%$. Samlet effekt var noe større, men mer usikker $(-1,76$ døgn; $95 \% \mathrm{KI}-3,48$ til -o,03, p = o,05, åtte studier, 671 pasienter) (figur 4). 


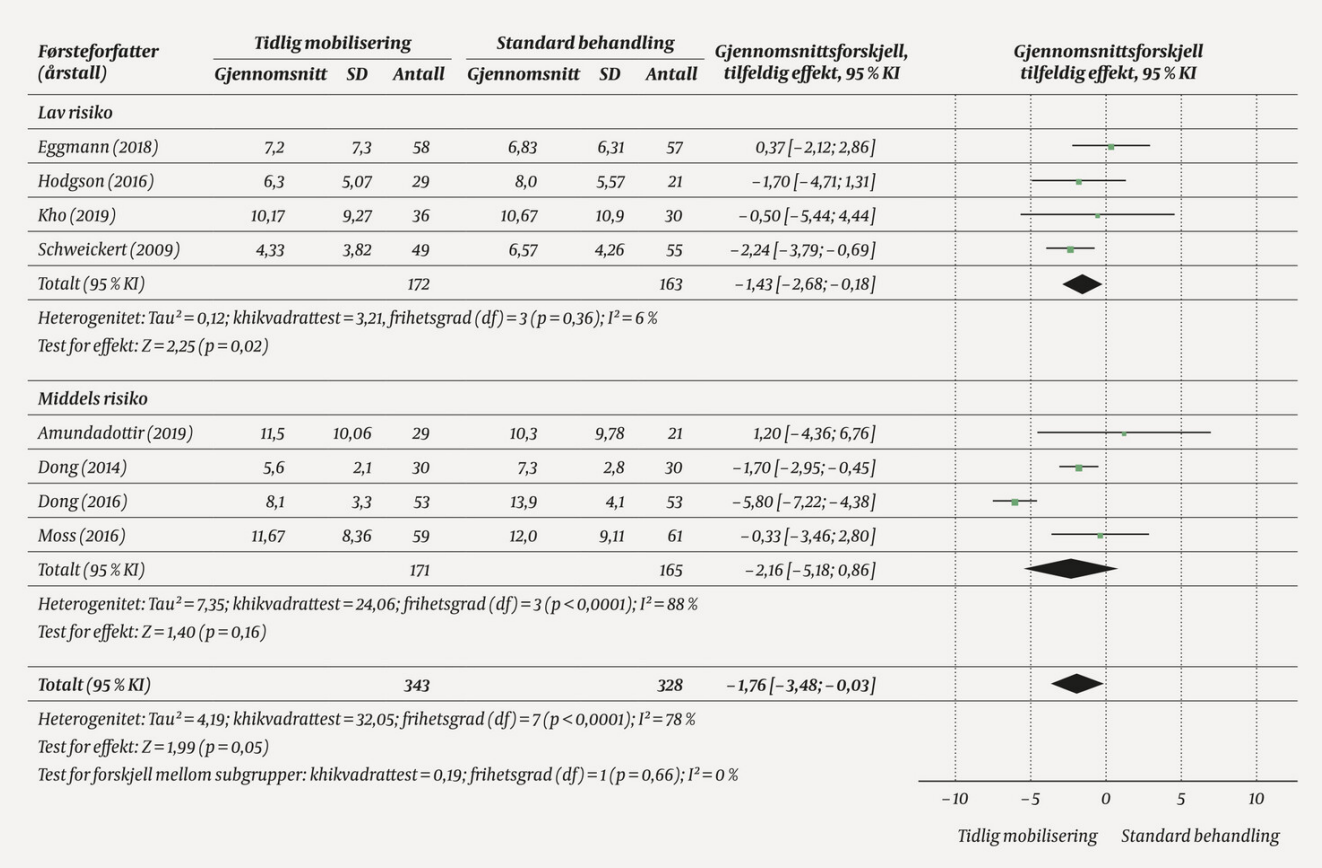

Figur 4 Balansediagram for utfallsmålet varighet av respiratorbehandling angitt i antall døgn.

Sammenligning mellom tidlig mobilisering og standard behandling. Studier med middels risiko for systematisk skjevhet er inkludert (subgrupper).

Inspirasjonsmuskeltrening versus standard behandling viste ingen effekt på varighet av respiratorbehandling (-o,11 døgn; $95 \% \mathrm{KI}-1,76$ til 1,53, $\mathrm{p}=0,89$, to studier, 146 pasienter), med liten tillit til dokumentasjonen (resultat ikke vist, kan fås ved å kontakte førsteforfatter).

Avvenningstid fra respirator ble ikke rapportert i studiene med tidlig mobilisering med lav risiko for systematisk skjevhet. Inspirasjonsmuskeltrening versus standard behandling viste ikke effekt (-o,33 døgn; $95 \%$ KI -1,31 til o,65, p = o,51, én studie, 77 pasienter), med liten tillit til dokumentasjonen (resultat ikke vist, kan fås ved å kontakte førsteforfatter).

Metaanalyser basert på dokumentasjonen med middels tillit, fant ingen effekt av treningen på dødelighet (resultat ikke vist, kan fås ved å kontakte førsteforfatter).

SEKUNDARUTFALL

Tidlig mobilisering versus standard behandling ga kortere liggetid i intensivavdeling (-1,08 døgn; $95 \% \mathrm{KI}-1,95$ til -o,21, $\mathrm{p}=0$,02, sju studier, 1143 pasienter), med middels tillit til dokumentasjonen (figur 5).

\begin{tabular}{|c|c|c|c|c|c|c|c|c|c|c|c|}
\hline \multirow{2}{*}{$\begin{array}{l}\text { Førsteforfatter } \\
\text { (årstall) }\end{array}$} & \multicolumn{3}{|c|}{ Tidlig mobilisering } & \multicolumn{3}{|c|}{ Standard behandling } & \multirow{2}{*}{$\begin{array}{l}\text { Gjennomsnittsforskjell, } \\
\text { tilfeldig effekt, } 95 \% \text { KI }\end{array}$} & \multirow{2}{*}{\multicolumn{4}{|c|}{$\begin{array}{l}\text { Gjennomsnittsforskjell } \\
\text { tilfeldigeffekt, } 95 \% \mathrm{KI}\end{array}$}} \\
\hline & Gjennomsnitt & SD & Antall & Gjennomsnitt & SD & Antall & & & & & \\
\hline Eggmann (2018) & 7,47 & 6,31 & 58 & 8,63 & 7,68 & 57 & $-1,16[-3,73 ; 1,41]$ & & $\ldots$ & & \\
\hline Hodgson (2016) & 10,67 & 8,58 & 29 & 12,67 & 8,75 & 21 & $-2,00[-6,87 ; 2,87]$ & & $\begin{array}{l:} \\
\end{array}$ & & \\
\hline Kho (2019) & 15,5 & 13,9 & 36 & 14,33 & 11,68 & 30 & $1,17[-5,00 ; 7,34]$ & & 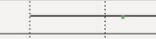 & - & \\
\hline Morris(2016) & 8,5 & 7,49 & 150 & 8,33 & 6,74 & 150 & $0,17[-1,44 ; 1,78]$ & & -- & & \\
\hline Schaller (2016) & 8,0 & 5,26 & 104 & 10,33 & 6,77 & 96 & $-2,33[-4,02 ;-0,64]$ & & - - & & \\
\hline Schweickert(2009) & 7,87 & 6,65 & 49 & 8,97 & 5,18 & 55 & $-1,10[-3,41 ; 1,21]$ & & $\because$ & & \\
\hline Wright (2017) & 14,0 & 9,73 & 150 & 15,33 & 11,22 & 158 & $-1,33[-3,67 ; 1,01]$ & & $\cdots:$ & & \\
\hline Totalt (95\% KI) & & & 576 & & & 567 & $-1,08[-1,95 ;-0,21]$ & & 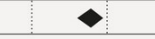 & & 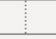 \\
\hline \multirow{2}{*}{\multicolumn{7}{|c|}{$\begin{array}{l}\text { Heterogenitet: } \text { Tau }^{2}=0,00 ; \text { khikvadrattest }=5,11 \text {, frihetsgrad }(d f)=6(p=0,53) ; I^{2}=0 \% \\
\text { Test for effekt: } Z=2,43(p=0,02)\end{array}$}} & \multirow{2}{*}{\multicolumn{3}{|c|}{$\begin{array}{lll}-10 & -5 & 0 \\
& \text { Tidligmobilisering } & \text { Star }\end{array}$}} & 5 & 10 \\
\hline & & & & & & & & & & lard behar & ndling \\
\hline
\end{tabular}

Figur 5 Balansediagram for utfallsmålet liggetid i intensivavdeling angitt i antall døgn.

Sammenligning mellom tidlig mobilisering og standard behandling. De inkluderte studiene har lav risiko for systematisk skjevhet.

Ved inklusjon av studier med middels risiko for systematisk skjevhet ble det betydelig større statistisk heterogenitet i analysene, $\mathrm{I}^{2}=76 \%$. Samlet effekt var noe st $\varnothing r r e$, men mer usikker $(-1,74$ døgn; 95\% KI -3,32 til-o,15, p = 0,03, 13 studier, 1597 pasienter) (figur 6). Det var ingen effekt på liggetid på sykehus (resultat ikke vist, kan fås ved å kontakte førsteforfatter), med middels tillit til dokumentasjonen. Ingen av studiene rapporterte effekt av inspirasjonsmuskeltrening på liggetid. 


\begin{tabular}{|c|c|c|c|c|c|c|c|c|c|c|c|}
\hline \multirow{2}{*}{$\begin{array}{l}\text { Forsteforfatter } \\
\text { (årstall) }\end{array}$} & \multicolumn{3}{|c|}{ Tidligmobilisering } & \multicolumn{3}{|c|}{ Standard behandling } & \multirow{2}{*}{$\begin{array}{l}\text { Gjennomsnittsforskjell, } \\
\text { tilfeldig effekt, } 95 \% \mathrm{KI}\end{array}$} & \multirow{2}{*}{\multicolumn{4}{|c|}{$\begin{array}{l}\text { Gjennomsnittsforskjell } \\
\text { tilfeldigeffekt, } 95 \% \mathrm{KI}\end{array}$}} \\
\hline & Gjennomsnitt & SD & Antall & Gjennomsnitt & $S D$ & Antall & & & & & \\
\hline \multicolumn{12}{|l|}{ Lav risiko } \\
\hline Eggmann (2018) & 7,47 & 6,31 & 58 & 8,63 & 7,68 & 57 & $-1,16[-3,73 ; 1,41]$ & & $\longrightarrow$ & & \\
\hline Hodgson (2016) & 10,67 & 8,58 & 29 & 12,67 & 8,75 & 21 & $-2,00[-6,87 ; 2,87]$ & $\div$ & $=$ & & \\
\hline Kho (2019) & 15,5 & 13,9 & 36 & 14,33 & 11,68 & 30 & $1,17[-5,00 ; 7,34]$ & & $:$ & $=$ & \\
\hline Morris(2016) & 8,5 & 7,49 & 150 & 8,33 & 6,74 & 150 & $0,17[-1,44 ; 1,78]$ & & $-\infty$ & & \\
\hline Schaller (2016) & 8,0 & 5,26 & 104 & 10,33 & 6,77 & 96 & $-2,33[-4,02 ;-0,64]$ & & $\longrightarrow$ & & \\
\hline Schweickert(2009) & 7,87 & 6,65 & 49 & 8,97 & 5,18 & 55 & $-1,10[-3,41 ; 1,21]$ & & $\begin{array}{c:c} \\
\cdots\end{array}$ & & \\
\hline Wright (2017) & 14,0 & 9,73 & 150 & 15,33 & 11,22 & 158 & $-1,33[-3,67 ; 1,01]$ & & $\begin{array}{c:c}C & \\
\end{array}$ & & \\
\hline Totalt (95\% KI) & & & 576 & & & 567 & $-1,08[-1,95 ;-0,21]$ & & 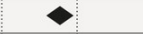 & & \\
\hline \multicolumn{12}{|c|}{$\begin{array}{l}\text { Heterogenitet: } \text { Tau }^{2}=0,00 ; \text { khikvadrattest }=5,11, \text { frihetsgrad }(d f)=6(p=0,53) ; I^{2}=0 \% \\
\text { Test for effekt: } Z=2,43(p=0,02)\end{array}$} \\
\hline \multicolumn{12}{|l|}{ Middels risiko } \\
\hline Amundadottir(2019) & 13,47 & 8,73 & 29 & 13,7 & 12,32 & 21 & $-0,23[-6,38 ; 5,92]$ & - & & - & \\
\hline Burtin (2009) & 25,67 & 16,85 & 45 & 25,0 & 13,02 & 45 & $0,67[-5,55 ; 6,89]$ & & & & \\
\hline Dong(2014) & 12,7 & 4,1 & 30 & 15,2 & 4,5 & 30 & $-2,50[-4,68 ;-0,32]$ & & $\longrightarrow$ & & \\
\hline Dong(2016) & 11,7 & 3,2 & 53 & 18,3 & 4,2 & 53 & $-6,60[-8,02 ;-5,18]$ & - & & & \\
\hline Dos Santos (2018) & 10,3 & 8,7 & 13 & 14,2 & 9,7 & 15 & $-3,90[-10,72 ; 2,92]$ & & : & & \\
\hline Moss(2016) & 16,67 & 11,4 & 59 & 16,67 & 10,63 & 61 & $0,00[-3,95 ; 3,95]$ & & - & & \\
\hline Totalt (95\% KI) & & & 229 & & & 225 & $-2,56[-5,49 ; 0,36]$ & & 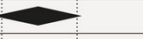 & & \\
\hline \multicolumn{12}{|c|}{$\begin{array}{l}\text { Heterogenitet: } \text { Tau }^{2}=8,51 ; \text { khikvadrattest }=21,13 \text {, frihetsgrad }(\mathrm{d} f)=5(p=0,0008) ; I^{2}=76 \% \\
\text { Testfor effekt: } Z=1,72(p=0,09)\end{array}$} \\
\hline Totalt ( $95 \% \mathrm{KI})$ & & & 805 & & & 792 & $-1,74[-3,32 ;-0,15]$ & & $<$ & & \\
\hline \multirow{2}{*}{\multicolumn{12}{|c|}{$\begin{array}{l}\text { Heterogenitet: }: \text { Tau }{ }^{2}=5,38 ; \text { khikvadrattest }=50,53 \text {, frihetsgrad }(d f)=12(p<0,00001) ; I^{2}=76 \% \\
\text { Test for effekt: } Z=2,15(p=0,03) \\
\text { Test for forskjell mellom subgrupper: khikvadrattest }=0,91 \text {, frihetsgrad }(d f)=1(p=0,34), I^{2}=0 \%\end{array}$}} \\
\hline & & & & & & & & & & & 10 \\
\hline
\end{tabular}

Figur 6 Balansediagram for utfallsmålet liggetid i intensivavdeling angitt i antall dager.

Sammenligning mellom tidlig mobilisering og standard behandling. Studier med middels risiko for systematisk skjevhet er inkludert (subgrupper).

Tilliten til dokumentasjonen og årsaker for nedgradering er oppsummert i tabell 2a og b, der GRADE-metoden er brukt for vurdering.

\section{Tabell 2a}

Resultattabell der tilliten til dokumentasjonen er vurdert etter GRADE-metoden. $\mathrm{MD}=$ gjennomsnittsforskjell, OR = oddsratio.

\begin{tabular}{|c|c|c|c|c|c|}
\hline \multirow[t]{2}{*}{ Utfallsmål } & \multicolumn{2}{|c|}{ Absolutt effekt (95\% KI) } & \multirow{2}{*}{$\begin{array}{l}\text { Relativ } \\
\text { effekt } \\
(95 \% \mathrm{KI})\end{array}$} & \multirow{2}{*}{$\begin{array}{l}\text { Antall } \\
\text { deltakere } \\
\text { (antall } \\
\text { studier) }\end{array}$} & \multirow{2}{*}{$\begin{array}{l}\text { Tillit til } \\
\text { dokumentasjonen } \\
\text { (GRADE) }\end{array}$} \\
\hline & $\begin{array}{l}\text { Risiko ved } \\
\text { standard } \\
\text { behandling }\end{array}$ & $\begin{array}{l}\text { Risiko ved } \\
\text { tidlig } \\
\text { mobilisering }\end{array}$ & & & \\
\hline $\begin{array}{l}\text { Varighet av } \\
\text { respiratorbehandling }\end{array}$ & & $\begin{array}{r}\text { MD 1,43 lavere } \\
\text { (2,68 lavere til } \\
0,18 \text { lavere) }\end{array}$ & - & $335(4)$ & Middels ${ }^{1}$ \\
\hline $\begin{array}{l}\text { Dødelighet på } \\
\text { sykehus }\end{array}$ & $\begin{array}{r}161 \text { per } \\
1000\end{array}$ & $\begin{array}{r}12 \text { per } 1000 \\
(55 \text { til } 42)\end{array}$ & $\begin{array}{r}\text { OR } 0,90 \\
(0,61 \text { til } \\
1,33)\end{array}$ & $835(6)$ & Middels ${ }^{2}$ \\
\hline $\begin{array}{l}\text { Dødelighet etter 1- } \\
3 \text { måneder }\end{array}$ & 73 per 1000 & $\begin{array}{r}34 \text { per } 1000 \\
(62 \text { til } 51)\end{array}$ & $\begin{array}{r}\text { OR } 0,51 \\
(0,14 \text { til } \\
1,80)\end{array}$ & $200(1)$ & Middels ${ }^{3}$ \\
\hline $\begin{array}{l}\text { Dødelighet etter 1- } \\
6 \text { måneder }\end{array}$ & $\begin{array}{r}200 \text { per } \\
1000\end{array}$ & $\begin{array}{r}20 \text { per } 1000 \\
(70 \text { til } 45)\end{array}$ & $\begin{array}{r}\text { OR } 0,95 \\
(0,54 \text { til } \\
1,65)\end{array}$ & $723(3)$ & Middels $^{2}$ \\
\hline $\begin{array}{l}\text { Liggetid i } \\
\text { intensivavdeling }\end{array}$ & - & $\begin{array}{r}M D \\
1,08 \text { lavere } \\
(1,95 \text { lavere til } \\
0,21 \text { lavere })\end{array}$ & - & $1143(7)$ & Middels ${ }^{2}$ \\
\hline
\end{tabular}




\begin{tabular}{|c|c|c|c|c|c|}
\hline \multirow[t]{2}{*}{ Utfallsmål } & \multicolumn{2}{|c|}{ Absolutt effekt (95\% KI) } & \multirow{2}{*}{$\begin{array}{l}\text { Relativ } \\
\text { effekt } \\
(95 \% \mathrm{KI})\end{array}$} & \multirow{2}{*}{$\begin{array}{l}\text { Antall } \\
\text { deltakere } \\
\text { (antall } \\
\text { studier) }\end{array}$} & \multirow{2}{*}{$\begin{array}{l}\text { Tillit til } \\
\text { dokumentasjonen } \\
\text { (GRADE) }\end{array}$} \\
\hline & $\begin{array}{l}\text { Risiko ved } \\
\text { standard } \\
\text { behandling }\end{array}$ & $\begin{array}{l}\text { Risiko ved } \\
\text { tidlig } \\
\text { mobilisering }\end{array}$ & & & \\
\hline Liggetid på sykehus & - & $\begin{array}{r}M D \\
0,62 \text { lavere } \\
(2,89 \text { lavere til } \\
1,65 \text { høyere })\end{array}$ & - & $1143(7)$ & Middels $^{2}$ \\
\hline
\end{tabular}

${ }^{1}$ Samlet antall deltakere er under 400

${ }^{2}$ Brede konfidensintervaller i studiene

${ }^{3}$ Det er kun én studie i analysen

\section{Tabell 2b}

Resultattabell der tilliten til dokumentasjonen er vurdert etter GRADE-metoden. $\mathrm{MD}=$ gjennomsnittsforskjell, OR = oddsratio.

\begin{tabular}{|c|c|c|c|c|c|}
\hline \multirow[t]{2}{*}{ Utfallsmål } & \multicolumn{2}{|c|}{ Absolutt effekt (95\% KI) } & \multirow{2}{*}{$\begin{array}{l}\text { Relativ } \\
\text { effekt } \\
(95 \% \mathrm{KI})\end{array}$} & \multirow{2}{*}{$\begin{array}{l}\text { Antall } \\
\text { deltakere } \\
\text { (antall } \\
\text { studier) }\end{array}$} & \multirow{2}{*}{$\begin{array}{l}\text { Tillit til } \\
\text { dokumentasjonen } \\
\text { (GRADE) }\end{array}$} \\
\hline & $\begin{array}{l}\text { Risiko ved } \\
\text { standard } \\
\text { behandling }\end{array}$ & $\begin{array}{l}\text { Risiko ved } \\
\text { inspirasjons- } \\
\text { muskeltrening }\end{array}$ & & & \\
\hline $\begin{array}{l}\text { Varighet av } \\
\text { respiratorbehandling }\end{array}$ & & $\begin{array}{r}\text { MD 0,11 lavere } \\
(1,76 \text { lavere til } \\
1,53 \text { høyere })\end{array}$ & - & $146(2)$ & Liten $^{1,2}$ \\
\hline $\begin{array}{l}\text { Avvenningstid fra } \\
\text { respirator }\end{array}$ & & $\begin{array}{r}\text { MD 0,33 lavere } \\
(1,31 \text { lavere til } \\
0,65 \text { høyere })\end{array}$ & - & $77(1)$ & Liten $^{1,3}$ \\
\hline $\begin{array}{l}\text { Dødelighet på } \\
\text { sykehus }\end{array}$ & 99 per 1000 & $\begin{array}{r}36 \text { per } 1000 \\
(78 \text { til } 77)\end{array}$ & $\begin{array}{r}\text { OR } 0,62 \\
(0,19 \text { til } \\
2,03)\end{array}$ & $161(2)$ & Middels $^{2}$ \\
\hline
\end{tabular}

${ }^{1}$ Samlet antall deltakere er under 400

${ }^{2}$ Brede konfidensintervaller i studiene

${ }^{3}$ Det er kun én studie i analysen

\section{SUBGRUPPEANALYSER}

Vi gjorde subgruppeanalyser av kontinuerlige variabler i alle studiene av tidlig mobilisering, med hensyn til antall behandlinger og hvor aktive tiltakene i kontrollgruppene var. Ingen av balansediagrammene viste signifikant forskjell mellom subgruppene (resultat ikke vist, kan fås ved å kontakte førsteforfatter).

\section{PASIENTSIKKERHET}

I 13 av de 17 inkluderte studiene ble det rapportert om hvorvidt det hadde forekommet uheldige hendelser (15), (18-22), (244-30). Rapporteringen var mangelfull i flere studier (appendiks 4). Kun to alvorlige hendelser var rapportert: bradykardi og saturasjonsfall til under $80 \%(\underline{15}, \underline{18})$. I studiene av inspirasjonsmuskeltrening var det rapportert om null hendelser $(\underline{\mathbf{2 2}}, \underline{\mathbf{2 4}} \mathbf{4})$. Det var ikke oppgitt antall $\emptyset$ kter. I sju studier av tidlig mobilisering var det oppgitt både antall uheldige hendelser og antall treningsøkter i intervensjonsgruppene $(\underline{20}, \underline{26})(\underline{28}-3 \underline{0})$. I disse studiene var det oppgitt totalt 79 uheldige hendelser i løpet av 5675 intervensjonsøkter, noe som tilsvarer 1,4\%. Vi har regnet med 35 hendelser i to studier som førte til at intervensjonen ble avbrutt tidlig $(\underline{\mathbf{2 1}}, \underline{\mathbf{2 2}}, \underline{24}$.). I

kontrollgruppene var det mangelfull rapportering av antall uheldige hendelser og/eller antall økter. Vi fant altså at intervensjonene medførte et lavt antall uheldige hendelser. Grunnlaget for å sammenligne med kontrollgruppene var mangelfullt. Fullstendig oversikt over alle uheldige hendelser i studiene finnes i appendiks 4 . 
I analysene av studier med lav risiko for systematisk skjevhet var det ikke grunnlag for sensitivitetsanalyser av omregnede verdier (resultat ikke vist, kan fås ved å kontakte førsteforfatter).

\section{Diskusjon}

Denne systematiske oversikten omfattet 17 randomiserte, kontrollerte studier av inspirasjonsmuskeltrening og tidlig mobilisering. Metaanalysene viser at tidlig mobilisering kan føre til kortere respiratorbehandlingstid og kortere liggetid i intensivavdeling. Vi fant ingen effekt av tidlig mobilisering på avvenningstid fra respirator, med kun én studie i sammenligningen. Tidlig mobilisering ga heller ingen effekt på dødelighet eller liggetid på sykehus. Analysene av inspirasjonsmuskeltrening viste ingen effekt på varighet av respiratorbehandling eller avvenningstid fra respirator eller på dødelighet på sykehus.

Dokumentasjonsgrunnlaget for inspirasjonsmuskeltrening var lite, og resultatene må tolkes med forsiktighet. Det var beskrevet få uheldige hendelser knyttet til bruken av tidlig mobilisering og inspirasjonsmuskeltrening, og kun to alvorlige uheldige hendelser.

Vi fant at tidlig mobilisering i gjennomsnitt reduserte varighet av respiratorbehandling med halvannet døgn sammenlignet med standard behandling. Connolly og medarbeidere fant også en positiv effekt av tidlig mobilisering på varighet av respiratorbehandling i sin oversikt over systematiske oversikter (32). Vi fant ingen effekt av inspirasjonsmuskeltrening på dette utfallsmålet. Reduksjon av respiratortiden er beskrevet som et mål i Norsk intensivregisters årsrapport fra 2019 (1). Kortere respiratortid vil trolig kunne føre til færre komplikasjoner, økt kapasitet og reduserte kostnader for intensivavdelingene.

Vi fant ingen studier med lav risiko for systematisk skjevhet der man hadde undersøkt effekten av tidlig mobilisering på avvenningstid fra respirator. Kun én studie av inspirasjonsmuskeltrening undersøkte dette utfallsmålet. Vorona og medarbeidere fant i sin systematiske oversikt av inspirasjonsmuskeltrening effekt på avvenningstiden fra respirator (33). Elkins og medarbeidere fant i sin systematiske oversikt at inspirasjonsmuskeltrening førte til høyere andel vellykkede avvenningsfors $ø \mathrm{k}$ fra respirator (34.). Avvenningstid fra respirator er et utfallmål som er avhengig av flere faktorer, blant annet hvilke kriterier man benytter for å kategorisere pasienten som avvenningsklar, samt hvordan selve avvenningen er gjennomført (34).

Våre analyser viste at verken tidlig mobilisering eller inspirasjonsmuskeltrening hadde effekt på dødelighet. I to tidligere systematiske oversikter der man sammenlignet tidlig mobilisering med standard behandling, fant man også lik dødelighet i gruppene $(35,3 \underline{6})$.

Tidlig mobilisering førte til om lag ett døgn kortere liggetid i intensivavdeling. Vi kunne ikke påvise effekt på liggetiden på sykehus. Kayambu og medarbeidere fant effekt på liggetid både i

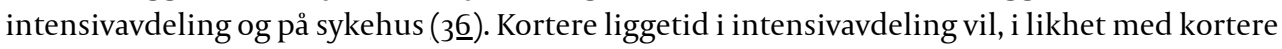
respiratorbehandlingstid, føre til færre komplikasjoner for pasientene og potensielt gi økt kapasitet og færre kostnader.

Vi fant få uheldige hendelser. Dette var rapportert i kun 1,4 \% av mobiliserings $\varnothing$ ktene i studiene. En tidligere systematisk oversikt og metaanalyse viste at uheldige hendelser forekom ved 2,6 \% av mobiliserings $\varnothing$ ktene og at dette fikk uheldige konsekvenser for pasientene i o,6 \% av tilfellene (37.). Det ble oppgitt null uheldige hendelser i studiene av inspirasjonsmuskeltrening. Det må tas høyde for at det kan være uheldige hendelser som ikke har blitt rapportert. Det er også en utfordring at uheldige hendelser er ulikt definert i studiene, og i noen studier er det heller ikke predefinert (111). Primærstudier har vist at tidlig mobilisering i intensivavdeling er trygt og gjennomførbart (37,3요).

Det er metodiske begrensninger i arbeidet vårt. Studiene av tidlig mobilisering hadde variasjon i tiltak både i intervensjons- og kontrollgrupper, og kontrollgruppenes tiltak var dårlig beskrevet i flere av studiene. Disse faktorene kan ha hatt innvirkning på resultatene, som kan ha blitt mer heterogene. Vi har gjort subgruppeanalyser for å forsøke å samle studier som er mer like, uten at vi fant signifikant forskjell mellom gruppene. Det er også et kjent problem innen intensivforskning, der man har en relativt høy tidlig dødelighet, at det kan være problematisk å få gode oppfølgingsdata. Utfallsmålene i denne oversikten kan være konfundert av dette (39.). 
Det er kun utført blinding i to av studiene i de presenterte metaanalysene $(\underline{21}, \underline{2} 3)$. Det er vanskelig å blinde deltakere og personell for intervensjonene vi har inkludert. Vi har gitt høy risiko for manglende blinding, men ikke trukket for dette i GRADE-metoden, fordi vi tror det ikke påvirket resultatene. Wood og medarbeidere fant i sin metaepidemiologiske oversikt med 146 metaanalyser lite bevis for at manglende blinding fører til overdrevet effekt ved objektive utfallsmål (씅).

Vi har harde utfallsmål som ikke sier noe om livskvalitet, selvhjulpenhet eller andre pasientrapporterte utfallsmål. Slike utfallsmål er klinisk relevante og av stor betydning for pasienter og pårørende. Tipping og medarbeidere fant at høy dose av tidlig mobilisering er assosiert med økt livskvalitet etter seks måneder (35).

Det er flere styrker ved vår systematiske oversikt og metaanalyse. Vi gjennomførte et grundig, systematisk litteraturs $\varnothing \mathrm{k}$. To uavhengige forfattere har bidratt i utvelgelsen av studier, ekstraksjon av data og kvalitetsvurderingen, noe som hever kvaliteten på arbeidet. Kvaliteten på studiene er også forholdsvis høy, ettersom vi ekskluderte studier med høy risiko for systematisk skjevhet.

Kliniske implikasjoner av analysene våre er at tidlig mobilisering av voksne intensivpasienter med respirator bør gjennomføres i praksis. Studier har vist at det er trygt og gjennomførbart $(3 \underline{8}, 4 \underline{1})$. Imidlertid finnes det en rekke opplevde barrierer som påvirker gjennomføringen av tidlig mobilisering på intensivavdeling (늘). Praksisstudier har vist at tidlig mobilisering av intensivpasienter i liten grad blir gjennomført $(43,444)$. $\varnothing v$ vrebø fant i sin studie om mobiliseringspraksis på intensivavdeling ved Stavanger universitetssjukehus at intensivpasienter første gang ble mobilisert etter i gjennomsnitt åtte døgn med respiratorbehandling. Det gikk i gjennomsnitt fem døgn fra pasientene var mobiliseringsklare til de ble mobilisert. På dagvakter ble $40 \%$ av mobiliseringsklare respiratorpasienter mobilisert, mens $21 \%$ av mobiliseringsklare respiratorpasienter ble mobilisert på kveldsvakter. Denne studien viser at det også i Norge er behov for kvalitetsarbeid med hensyn til tidlig mobilisering av intensivpasienter med respiratorbehandling (45).

Det pågår en del studier av alle intervensjonene vi har undersøkt. Det vil være spesielt interessant å følge studiene om sengesykling, ettersom de fleste eksisterende studiene undersøker sikkerhet og gjennomførbarhet ved denne typen mobilisering.

KONKLUSJON

Denne systematiske oversikten og metaanalysen viser at tidlig mobilisering av voksne intensivpasienter med respiratorbehandling kan føre til kortere respiratorbehandlingstid og kortere liggetid i intensivavdeling. Intervensjonen ga ingen effekt på dødelighet. Vi fant ingen effekt av inspirasjonsmuskeltrening på varighet av respiratorbehandling, avvenningstid fra respirator eller dødelighet på sykehus. Det er forholdsvis få studier der man har undersøkt inspirasjonsmuskeltrening, og vi trenger fremtidige studier der denne intervensjonen blir gjennomgått. Også pasientrapporterte utfallsmål på lang sikt bør undersøkes, og i årene som kommer, vil studier forhåpentligvis også si mer om effekten av sengesykling.

Takk til Mikaela Aamodt for hjelp med oppdaterte søk. Takk også til Kristin Brautaset for faglige og metodetekniske innspill.

Artikkelen er fagfellevurdert.

HOVEDFUNN

Tidlig mobilisering av respiratorpasienter gir trolig litt kortere respiratorbehandlingstid. Inspirasjonsmuskeltrening har muligens liten eller ingen effekt på avvenningstid fra respirator. Tidlig mobilisering og inspirasjonsmuskeltrening har trolig ingen effekt på dødelighet, og det er rapportert få uheldige hendelser.

\section{LITTERATUR}

1. Buanes EA, Kvåle R, Barratt-Due A. Årsrapport for 2019 med plan for forbetringstiltak. Versjon 1.1. Bergen: Norsk intensivregister, 2020. 
https://www.kvalitetsregistre.no/sites/default/files/37_arsrapport2019_norsk_intensivregister.pdf Lest 19.3.2021.

2. Puthucheary ZA, Rawal J, McPhail M et al. Acute skeletal muscle wasting in critical illness. JAMA 2013; 310: 1591-6oo. [PubMed][CrossRef]

3. Parry SM, El-Ansary D, Cartwright MS et al. Ultrasonography in the intensive care setting can be used to detect changes in the quality and quantity of muscle and is related to muscle strength and function.J Crit Care 2015; 30: 1151.e9-14. [PubMed][CrossRef]

4. Needham DM. Mobilizing patients in the intensive care unit: improving neuromuscular weakness and physical function. JAMA 2008; 300: 1685-90. [PubMed][CrossRef]

5. Cameron S, Ball I, Cepinskas G et al. Early mobilization in the critical care unit: A review of adult and pediatric literature. J Crit Care 2015; 30: 664-72. [PubMed][CrossRef]

6. Moodie L, Reeve J, Elkins M. Inspiratory muscle training increases inspiratory muscle strength in patients weaning from mechanical ventilation: a systematic review. J Physiother 2011; 57: 213-21. [PubMed][CrossRef]

7. Zhang L, Hu W, Cai Z et al. Early mobilization of critically ill patients in the intensive care unit: A systematic review and meta-analysis. PLoS One 2019; 14: e0223185. [PubMed][CrossRef]

8. Schünemann H, Brożek J, Guyatt G et al. GRADE handbook for grading quality of evidence and strength of recommendations: The GRADE Working Group, 2013. https://gdt.gradepro.org/app/handbook/handbook.html Lest 19.3.2021.

9. Moher D, Liberati A, Tetzlaff J et al. Preferred reporting items for systematic reviews and meta-analyses: the PRISMA statement. BMJ 2009; 339: b2535. [PubMed][CrossRef]

10. National Institute for Health Research. Prospero. https://www.crd.york.ac.uk/PROSPERO/ Lest 19.3.2021.

11. Peryer G, Golder S, Junqueira D et al. Chapter 19: Adverse effects. I: Cochrane Handbook for Systematic Reviews of Interventions version 61. https://training.cochrane.org/handbook/current/chapter-19 Lest 19.3.2021.

12. Review Manager (RevMan). Dataprogram. 5.3 ed. København: The Nordic Cochrane Centre, The Cochrane Collaboration, 2014

13. Wan X, Wang W, Liu J et al. Estimating the sample mean and standard deviation from the sample size, median, range and/or interquartile range. BMC Med Res Methodol 2014; 14: 135. [PubMed][CrossRef]

14. Higgins JPT, Thomas J, Chandler J et al. Kapittel 8. I: Cochrane Handbook for Systematic Reviews of Interventions. 2. utgave. Chichester: John Wiley \& Sons, 2019.

15. Burtin C, Clerckx B, Robbeets C et al. Early exercise in critically ill patients enhances short-term functional recovery. Crit Care Med 2009; 37: 2499-505. [PubMed][CrossRef]

16. Dong Z, Yu B, Zhang Qet al. Early rehabilitation therapy is beneficial for patients with prolonged mechanical ventilation after coronary artery bypass surgery. Int Heart J 2016; 57: 241-6. [PubMed][CrossRef]

17. Dantas CM, Silva PF, Siqueira FH et al. Influence of early mobilization on respiratory and peripheral muscle strength in critically ill patients. Rev Bras Ter Intensiva 2012; 24: 173-8. [PubMed][CrossRef]

18. Hodgson CL, Bailey M, Bellomo R et al. A binational multicenter pilot feasibility randomized controlled trial of early goal-directed mobilization in the ICU. Crit Care Med 2016; 44: 1145-52. [PubMed][CrossRef]

19. Moss M, Nordon-Craft A, Malone D et al. A randomized trial of an intensive physical therapy program for patients with acute respiratory failure. Am J Respir Crit Care Med 2016; 193: 1101-10. [PubMed][CrossRef]

20. Morris PE, Berry MJ, Files DC et al. Standardized rehabilitation and hospital length of stay among patients with acute respiratory failure: A randomized clinical trial. JAMA 2016; 315: 2694-702. [PubMed][CrossRef]

21. Martin AD, Smith BK, Davenport PD et al. Inspiratory muscle strength training improves weaning outcome in failure to wean patients: a randomized trial. Crit Care 2011; 15: R84. [PubMed][CrossRef]

22. Condessa RL, Brauner JS, Saul AL et al. Inspiratory muscle training did not accelerate weaning from mechanical ventilation but did improve tidal volume and maximal respiratory pressures: a randomised trial. J Physiother 2013; 59: 101-7. [PubMed][CrossRef]

23. Dos Santos FV, Cipriano G, Vieira L et al. Neuromuscular electrical stimulation combined with exercise decreases duration of mechanical ventilation in ICU patients: A randomized controlled trial. Physiother Theory Pract 2020; 36: 580-8. [PubMed][CrossRef]

24. Tonella RM, Ratti LDSR, Delazari LEB et al. Inspiratory muscle training in the intensive care unit: A new perspective. J Clin Med Res 2017; 9: 929-34. [PubMed][CrossRef]

25. Schaller SJ, Anstey M, Blobner M et al. Early, goal-directed mobilisation in the surgical intensive care unit: a randomised controlled trial. Lancet 2016;388:1377-88. [PubMed][CrossRef]

26. Schweickert WD, Pohlman MC, Pohlman AS et al. Early physical and occupational therapy in mechanically ventilated, critically ill patients: a randomised controlled trial. Lancet 2009; 373: 1874-82. [PubMed][CrossRef]

27. Dong ZH, Yu BX, Sun YB et al. Effects of early rehabilitation therapy on patients with mechanical ventilation. World J Emerg Med 2014; 5: 48-52. [PubMed][CrossRef]

28. Wright SE, Thomas K, Watson $\mathrm{G}$ et al. Intensive versus standard physical rehabilitation therapy in the critically ill (EPICC): a multicentre, parallel-group, randomised controlled trial. Thorax 2018; 73: 213-21. [PubMed][CrossRef]

29. Eggmann S, Verra ML, Luder G et al. Effects of early, combined endurance and resistance training in mechanically ventilated, critically ill patients: A randomised controlled trial. PLoS One 2018; 13: e0207428. 
30. Kho ME, Molloy AJ, Clarke FJ et al. Multicentre pilot randomised clinical trial of early in-bed cycle ergometry with ventilated patients. BMJ Open Respir Res 2019; 6: eoo0383. [PubMed][CrossRef]

31. Amundadottir OR, Jonasdottir RJ, Sigvaldason K et al. Effects of intensive upright mobilisation on outcomes of mechanically ventilated patients in the intensive care unit: a randomised controlled trial with 12-months follow-up. Eur J Physiother 2019; 21: 68-78. [CrossRef]

32. Connolly B, O'Neill B, Salisbury L et al. Physical rehabilitation interventions for adult patients during critical illness: an overview of systematic reviews. Thorax 2016; 71: 881-9o. [PubMed][CrossRef]

33. Vorona S, Sabatini U, Al-Maqbali S et al. Inspiratory muscle rehabilitation in critically ill adults. A systematic review and meta-analysis. Ann Am Thorac Soc 2018; 15: 735-44. [PubMed][CrossRef]

34. Elkins $\mathrm{M}$, Dentice R. Inspiratory muscle training facilitates weaning from mechanical ventilation among patients in the intensive care unit: a systematic review. J Physiother 2015; 61: 125-34. [PubMed][CrossRef]

35. Tipping CJ, Harrold M, Holland A et al. The effects of active mobilisation and rehabilitation in ICU on mortality and function: a systematic review. Intensive Care Med 2017; 43: 171-83. [PubMed][CrossRef]

36. Kayambu G, Boots R, Paratz J. Physical therapy for the critically ill in the ICU: a systematic review and metaanalysis. Crit Care Med 2013; 41: 1543-54. [PubMed][CrossRef]

37. Nydahl P, Sricharoenchai T, Chandra S et al. Safety of patient mobilization and rehabilitation in the Intensive Care Unit. Systematic review with meta-analysis. Ann Am Thorac Soc 2017; 14: 766-77. [PubMed] [CrossRef]

38. Bailey P, Thomsen GE, Spuhler VJ et al. Early activity is feasible and safe in respiratory failure patients. Crit Care Med 2007; 35: 139-45. [PubMed][CrossRef]

39. Egleston BL, Scharfstein DO, Freeman EE et al. Causal inference for non-mortality outcomes in the presence of death. Biostatistics 2007; 8: 526-45. [PubMed][CrossRef]

40. Wood L, Egger M, Gluud LL et al. Empirical evidence of bias in treatment effect estimates in controlled trials with different interventions and outcomes: meta-epidemiological study. BM] 2008; 336: 601-5. [PubMed] [CrossRef]

41. Sricharoenchai T, Parker AM, Zanni JM et al. Safety of physical therapy interventions in critically ill patients: a single-center prospective evaluation of 1110 intensive care unit admissions. J Crit Care 2014; 29:395-400. [PubMed][CrossRef]

42. Dubb R, Nydahl P, Hermes C et al. Barriers and strategies for early mobilization of patients in Intensive Care Units. Ann Am Thorac Soc 2016; 13: 724-30. [PubMed][CrossRef]

43. Berney SC, Harrold M, Webb SA et al. Intensive care unit mobility practices in Australia and New Zealand: a point prevalence study. Crit Care Resusc 2013; 15: 260-5. [PubMed]

44. Nydahl P, Ruhl AP, Bartoszek G et al. Early mobilization of mechanically ventilated patients: a 1-day pointprevalence study in Germany. Crit Care Med 2014; 42: 1178-86. [PubMed][CrossRef]

45. Øvrebø L, Hansen BS. Mobiliseringsaktivitet hos intensivpasienter. Inspira Tidsskrift for anestesi- og intensivsykepleiere 2019; 2: 16-23.

Publisert: 12. mai 2021. Tidsskr Nor Legeforen. DOI: 10.4045/tidsskr.20.0351

Mottatt 20.4.2020, første revisjon innsendt 29.6.2020, godkjent 19.3.2021.

Publisert under åpen tilgang CC BY-ND. Lastet ned fra tidsskriftet.no 26. april 2023. 